\title{
Prevalence of Lumbar Pain in Professional Truckers in The City of Tabuleiro Norte
}

\author{
Matheus Diógenes da Silva ${ }^{1}$, Roque Ribeiro da Silva Júnior ${ }^{2 *}$, Jaislane Lopes Silva ${ }^{3}$, Natália Rodrigues Macário ${ }^{4}$, Daniela \\ Maria Silva Maia ${ }^{5}$, Kariza Lopes Barreto ${ }^{6}$, Ligia Fernanda de Araújo ${ }^{7}$ \& Marcília Ingrid Lima Barroso Nunes ${ }^{8}$
}

${ }^{I}$ Faculdade do Vale do Jaguaribe - FVJ, Rodovia CE-040, S/N - Aeroporto, Aracati - CE. ${ }^{2}$ Universidade do Estado do Rio Grande do Norte - UERN, Rua Atirador Miguel Antônio da Silva, S/N - Aeroporto, Mossoró - RN. ${ }^{3}$ Faculdade do Vale do Jaguaribe - FVJ, Rodovia CE-040, S/N - Aeroporto, Aracati - CE. ${ }^{4}$ Faculdade do Vale do Jaguaribe - FVJ, Rodovia CE-040, S/N - Aeroporto, Aracati - CE. ${ }^{5}$ Faculdade do Vale do Jaguaribe - FVJ, Rodovia CE-040, S/N Aeroporto, Aracati - CE. ${ }^{6}$ Faculdade do Vale do Jaguaribe - FVJ, Rodovia CE-040, S/N - Aeroporto, Aracati - CE. ${ }^{7}$ Universidade do Estado do Rio Grande do Norte - UERN, Rua Atirador Miguel Antônio da Silva, S/N - Aeroporto, Mossoró - RN. ${ }^{8}$ Universidade do Estado do Rio Grande do Norte - UERN, Rua Atirador Miguel Antônio da Silva, S/N - Aeroporto, Mossoró - RN. Email: roquejunior@alu.uern.br*

DOI: http://doi.org/10.38177/ajast.2021.5301

Crossref

Copyright: (C) 2021 Matheus Diógenes da Silva et al. This is an open access article distributed under the terms of the Creative Commons Attribution License, which permits unrestricted use, distribution, and reproduction in any medium, provided the original author and source are credited.

\section{ABSTRACT}

Introduction: Low back pain is characterized by pain between the last rib and the gluteal region. It can be classified into acute, subacute, chronic specific and nonspecific. Being caused by several factors and affecting several professionals, among them, truckers. Objective: to investigate the prevalence of low back pain in truckers in the city of Tabuleiro do Norte. Methodology: this is a cross-sectional research, observational, exploratory, quantitative and with a probabilistic sample, whose population are truckers associated with ACATAN, aged between 23 and 65 years old and residing in Tabuleiro de Norte. Results: it was observed that the majority of truckers are between 33 and 42 years old (36\%), have grade II obesity (46\%) and have over 21 years of profession (38\%). In addition, $62 \%$ of these work as freelancers, spend more than 16 hours driving per day (40\%), making 2 trips per month (78\%), lasting 10 to 14 days (80\%) each and sleeping less than 6 hours (64\%) Conclusion: there is a prevalence of $68 \%$ low back pain in truckers associated with ACATAN. However, it is suggested that further studies be carried out with a larger number of participants.

Keywords: Low back pain, Physiotherapy, Prevalence, Truckers.

\section{Introduction}

Low back pain (LBP) or lumbago is characterized by the sensation of pain between the last rib and the inferior gluteal region, which may or may not be radiated to the legs [1]. This condition causes pain, discomfort, fatigue, or muscle stiffness of the spine [2]. It is estimated that low back pain is a condition that can affect $65 \%$ of people annually or up to approximately $84 \%$ of the population at some point in life, with an approximate prevalence of $11.9 \%$ in the world population [3,1]. In Brazil, according to the National Household Sample Survey (NHSS) of the Brazilian Institute of Geography and Statistics, back pain (cervical, thoracic and lumbar) represents the second most prevalent pathology, $13.5 \%$ among chronic diseases identified by a health professional, with Systemic Arterial Hypertension being considered the first. However, the study does not distinguish specific values for low back pain [4]. Thus, back pain is considered a serious public health problem, considering that it affects a large portion of the Brazilian population. In addition, it has a high cost for the national health and social security system, entailing many expenses with regard to diagnosis, therapy, early retirement and absence from work [5].

As for its classification, low back pain can be specific, having as its etiology congenital, degenerative, inflammatory, infectious and tumoral causes; and nonspecific, whose etiology is unknown, representing the majority of spinal pain [6]. In addition, it can also be classified, according to its duration, into acute (sudden onset and duration less than six weeks), subacute (duration 6 to 12 weeks) and chronic (duration greater than 12 weeks) [7]. Several factors may be related to the onset of LBP, including: biopsychosocial, economic, demographic factors, related to lifestyle, age, gender, sedentary lifestyle, obesity, smoking, population aging, inadequate posture at work, among others [8,9]. Among the reasons related to work, we can highlight excess load, physical effort, 
repetitive movements, lifting heavy objects, prolonged stay in the same posture and the inadequate work environment. Added to all this, psychological aspects must also be taken into account, such as the high demands of the market and the exhausting hours of work [8]. In this context, among the many professions that can be affected by LBP, we can emphasize cargo transport professionals, who can present up to three times more risks of developing such a problem [10]. This is because they are subjected to poor working conditions, sleepless nights, poor eating habits and are exposed to long hours of work, remaining in a sitting position for a long time [11].

Furthermore, the intense pace of work, the long distances to be covered, the demand to deliver the goods on time, the poor conditions of the highways and the violence present on the roads and in large urban centers may be associated with this. Above all, there is also the emotional factor, such as missing family members and loneliness for long hours driving alone, causing physical and mental wear and tear that increases the probability of these professionals to develop LBP [11,12]. Taking into account, therefore, the problem presented, it is important to contextualize that the city of Tabuleiro do Norte has an accessible location to the main interstate and national roads, which allows the flow of products. For this reason, its economy was mainly focused on cargo transportation, an activity that has been present since the historical beginning of the municipality [13].

Therefore, there was a need for assistance aimed at truck drivers, such as the structuring of the Metal Mechanic Pole and the creation, in 1992, of the Association of Truck Drivers of Tabuleiro do Norte (ACATAN). This association was the first one founded in the Northeast and aimed to bring together truck drivers in the fight for their interests. With the foundation of this association and because it concentrates a large number of truck drivers and truck owners, Tabuleiro became known nationally, since the 1990s, as the "Truck Drivers City" [13,12]. With this in mind, given what has been exposed about LBP, physical therapists can work with intervention strategies aimed at preventing this type of injury, performing stretching and muscle strengthening activities. Furthermore, this professional can also promote health education for different groups of workers, including truck drivers [14]. It is in this sense, therefore, that this study seeks to answer the question: what does the prevalence of low back pain in professional truck drivers in the city of Tabuleiro do Norte?

Thus, the present work is justified due to the large number of these professionals in the city of Tabuleiro do Norte, as well as the various damages of this pathology on workers' health. Furthermore, it is important to compare the results with other upcoming studies. Finally, it is noteworthy that the construction of research on this theme will certainly contribute to generate new knowledge and scientific enrichment. Thus, this study aimed to investigate the prevalence of low back pain in truck drivers in the city of Tabuleiro do Norte. Therefore, we seek to know the reality experienced by them, as well as to verify the impacts generated by the LBP in this working class.

\section{Methodology}

The present work is a cross-sectional study, is discussed in a given period of time. For this, the observational field research investigation approach was used, of an exploratory nature and with a quantitative approach, characterized by a type of probabilistic sample. In this sense, quantitative studies translate opinions and information into numbers so that they can be classified and analyzed [15]. According to data provided by ACATAN, the total population that meets the inclusion criteria is composed of 425 participants. For this purpose, in order to obtain the sample 
calculation, the "COMMENTTO" prepared by the authors Nookdzij, Dekker, Zocalli and Jager[16]. Calculator was used, with a maximum sampling error of 5\% and, therefore, with a reliability level of $95 \%$. This distribution of the chosen population, in turn, was framed as more homogeneous, resulting in a total of 156 participants. Of these, 15 refused to sign the consent form, and it was not possible to have contact with 91 participants because they were traveling during the collection period. Thus, the total number of participants approached was 50 truck drivers.

Data collection took place between April 21 and 30, 2021, at the association of truck drivers in Tabuleiro do Norte, at random and for convenience, until reaching the minimum number of people. During this process, it was explained in detail to all participants about the object and objective of the research. To do so, the researcher clarified the doubts, making it clear that the participant could leave the research at any time without suffering any damage or loss. Thus, the application of the questionnaire only took place after signing the Informed Consent Form (ICF). It is noteworthy that all preventive measures were taken to combat contamination with COVID 19.

This study included only truck drivers associated with ACATAN, aged between 23 and 65 years and male, in regular activity in the exercise of their profession and residing in the city of Tabuleiro do Norte. On the other hand, those who had a diagnosis of chronic pathology in the lumbar region before exercising the profession and those who did not want to undergo the informed consent were excluded.

Nevertheless, the risks were minimal: some truck drivers might just feel uncomfortable answering the form, causing embarrassment to the point of not wanting to participate in the research, as well as they might not accept submission to the IC, for fear of exposing the data obtained.

On the other hand, among the benefits of carrying out this research, we can highlight the actual obtainment of the prevalence of Low Back Pain in truck drivers, which is an important step to reveal the scope and magnitude of its effects on these professionals, providing better guidance for specific measures can be taken.

The Roland Morris questionnaire, chosen because it covers a general population with an aspect of low disability, was applied. It was tested and validated by Deyo, in 1986, and validated for Portuguese by Nusbaum, in 2000. This questionnaire has 24 items to describe the functionality of patients with low back pain. For each checked item a point is assigned. Thus, the final result corresponds to the sum of this score, the minimum being zero, which indicates that there is no impact of lumbar pain in the questioned person. On the other hand, the maximum value, 24 , indicates the degree of functional incapacity [16].

An authorial form was also applied to learn about the professional profile of truck drivers: their life habits and how trips are made.

Finally, the data were organized in tables, using Microsoft Excel, for the results comparison phase, which were registered in a report and presented orally, with the help of slides, for the examination of the panel.

To carry out this research, the rules provided for in resolution 466/12 and 510/16 of the National Health Council were followed. Therefore, the fundamental bioethical principles of the individual (autonomy), beneficence (including non-maleficence) and justice were preserved. For this reason, this study was approved by the Research Ethics Committee (REC) of the Faculdade do Vale do Jaguaribe, under Opinion No. 4,659,535. 


\section{Results}

The sample of this study had the participation of 50 male truck drivers, linked to the association of truck drivers of Tabuleiro do Norte (ACATAN). In table 1, there is the profile of the truck drivers, noting that the greatest amount of age comprises the range of 33 to 42 years, representing 36\%. Then the range between 43 and 52 years comprises $28 \%$. Finally, the intervals of 23 to 32 years and 53 years or more presented $18 \%$ each.

In addition, anthropometric data were also measured, from which it was possible to observe that $46 \%$ have type II obesity; $44 \%$ are overweight; $6 \%$ have a normal Body Mass Index (BMI); and 4\% have grade III obesity.

Table 01. Profile of study participants

\begin{tabular}{lcc}
\hline Age group 23 to 32 years old & $\mathrm{n}=9$ & $18 \%$ \\
33 to 42 years old & $\mathrm{n}=18$ & $36 \%$ \\
43 to 52 years old & $\mathrm{n}=14$ & $28 \%$ \\
53 years or older & $\mathrm{n}=9$ & $18 \%$ \\
& & \\
Normal body mass index (BMI) (18.5 to 24.9) & $\mathrm{n}=3$ & $6 \%$ \\
Overweight I (25 to 29.9) & $\mathrm{n}=22$ & $44 \%$ \\
Obesity II (30 to 39.9) & $\mathrm{n}=23$ & $46 \%$ \\
Obesity III (< 40) & $\mathrm{n}=2$ & $4 \%$ \\
\hline
\end{tabular}

Source: Survey data (2021)

In relation to the length of experience in the truck driver profession, it was observed that $38 \%$ are over 21 years old, $22 \%$ have 11 to 15 years, $16 \%$ have 1 to 5 years and that the intervals of 6 to 10 years and from 16 to 20 presented $12 \%$ each. Regarding ownership of the vehicle used to carry out activities, $62 \%$ of truck drivers are self-employed, while $38 \%$ report to owners of fleets or private trucks.

As for the average number of hours used per day to complete routes, $40 \%$ spend 16 hours or more on the road; $30 \%$, from 8 to 12 hours; $28 \%, 12$ to 16 hours; and only $2 \%$ spend less than 8 hours a day driving. Added to this, it is important to highlight that $76 \%$ of these workers make at least 2 trips per month; $16 \%$ manage to do twice that: 4 routes a month, which equates to approximately 1 trip per week; while only $8 \%$, which is equivalent to four of the survey participants, claimed to make only 1 trip per month.

With regard to the duration of the trips, $80 \%$ of the truck drivers stated that it takes 10 to 14 days to complete the complete round trip route; $12 \%$ indicate that it takes less than 10 days to complete the entire journey. Meanwhile, $4 \%$ of these workers assert that completing the route can take 15 to 20 days. And, with the same percentage of $4 \%$, that is, only 2 of those questioned declared that it would take more than 20 days to complete the entire trajectory. However, what stands out most in these data is that, when analyzing the time of hours allocated to sleep, $64 \%$ of the questioned drivers said they sleep less than 6 hours a day, which indicates that most of these professionals are 


\section{AJAST}

Asian Journal of Applied Science and Technology (AJAST)

Volume 5, Issue 3, Pages 01-12, July-September 2021

driving without the sleep necessary minimum required by the body and, consequently, causing damage to their own health. However, only $36 \%$ reported having at least 6 hours or more dedicated to sleep. (Table 02).

Table 02. Characteristics and data related to the work profession time

\begin{tabular}{lll}
\hline 1 to 5 years & $\mathrm{n}=8$ & $16 \%$ \\
6 to 10 years & $\mathrm{n}=6$ & $12 \%$ \\
11 to 15 years & $\mathrm{n}=11$ & $22 \%$ \\
16 to 20 years & $\mathrm{n}=6$ & $12 \%$ \\
Over 21 years old & $\mathrm{n}=19$ & $38 \%$
\end{tabular}

Truck:

Self-employed

$\mathrm{n}=31$

$62 \%$

Employee

$\mathrm{n}=19$

$38 \%$

Average time, in hours, driven per day

Less than $8 \mathrm{hrs}$

$\mathrm{n}=1$

$2 \%$

8 to $12 \mathrm{hrs}$

$\mathrm{n}=15$

$30 \%$

12 to $16 \mathrm{hrs}$

$\mathrm{n}=14$

$28 \%$

More than $16 \mathrm{hrs}$

$\mathrm{n}=20$

$40 \%$

How many trips per month do

1

2

3

4

Average time of travel days

Less than 10 days

$\mathrm{n}=6$

$12 \%$

10 to 14 days

$\mathrm{n}=40$

$80 \%$

15 to 20 days

More than 20 days

Average hours of sleep per day

Less than 6hrs

$\mathrm{n}=32$

$64 \%$

6 hours or more

$\mathrm{n}=18$

Source: Survey data (2021) 


\section{AJAST}

Asian Journal of Applied Science and Technology (AJAST)

Volume 5, Issue 3, Pages 01-12, July-September 2021

In addition, in Table 3, when asked about how the truck drivers participating in this research, assess their own health in the last 3 months, $62 \%$ assessed it as good; $22 \%$ as great; $14 \%$, median and $2 \%$ as bad. Regarding diseases associated with bad health habits, $74 \%$ did not have any such pathology. However, $22 \%$ reported having arterial hypertension; $6 \%$, high cholesterol; and $2 \%$ diabetes mellitus. Such data are justifiable when research participants claim to drink alcoholic beverages (52\%), use nobesio/rivet (40\%) and smoke (4\%). However, 14 of those questioned, $28 \%$, did not report on the subject.

Table 03. Conditions related to health and health habits

\begin{tabular}{lcc}
\hline How do you rate your health in the last 3 months? & & \\
Very Bad & $\mathrm{n}=0$ & $0 \%$ \\
Bad & $\mathrm{n}=1$ & $2 \%$ \\
Median & $\mathrm{n}=7$ & $14 \%$ \\
Good & $\mathrm{n}=31$ & $62 \%$ \\
Great & $\mathrm{n}=11$ & $22 \%$ \\
& & \\
Do you have any of these diseases? & & \\
Arterial hypertension & $\mathrm{n}=11$ & $22 \%$ \\
Diabetes Mellitus & $\mathrm{n}=1$ & $2 \%$ \\
High cholesterol & $\mathrm{n}=3$ & $6 \%$ \\
Disc herniation & $\mathrm{n}=0$ & $0 \%$ \\
Did not shown & $\mathrm{n}=37$ & $74 \%$ \\
& & $\mathrm{n}=2$ \\
Smoking habits & $\mathrm{n}=2 \%$ \\
Drinks, alcoholic beverages & $\mathrm{n}=26$ & $52 \%$ \\
Uses nobésio/rivet & $\mathrm{n}=20$ & $40 \%$ \\
Did not report & $\mathrm{n}=14$ & $28 \%$ \\
\hline
\end{tabular}

Source: Survey data (2021)

With regard to low back pain (Table 04), 32\% of truck drivers claimed not to feel this pain. However, $68 \%$ of them claimed to experience this symptom. Of these, $35.3 \%$ rated the pain as severe ( 5 or 6 on the VAS scale); followed by $20.6 \%$ who considered it to be very severe pain ( 7 or 8 on the VAS scale); and $8.8 \%$ classified it as mild pain ( 1 or 2 on the VAS scale).

Finally, $17.65 \%$ rated the pain as moderate ( 3 or 4 on the VAS scale) and, in the same proportion, 6 truck drivers categorized the pain as unbearable ( 9 or 10 on the VAS scale). As a result, while $11.8 \%$ of the truck drivers participating in this study reported not having any type of disability ( 0 to 3 scores), $55.9 \%$ claimed to have mild 


\section{AJAST}

Asian Journal of Applied Science and Technology (AJAST)

Volume 5, Issue 3, Pages 01-12, July-September 2021

disability (4 to 12 scores); $29.4 \%$ reported having moderate disability (13 to 17 scores); and $2.9 \%$ severe disability (>18 scores), with mean of 8.6 and a standard deviation of \pm 5 . (Table 04).

Table 04. Prevalence of low back pain and degree of disability (Roland Morris)

Do you feel low back pain?

Yes

$\mathrm{n}=34$

$68 \%$

No

$\mathrm{n}=16$

$32 \%$

Visual analogue scale (VAS)

1 or 2 (mild pain)

$\mathrm{n}=38$

$80 \%$

3 or 4 (moderate pain)

$\mathrm{n}=6$

5 or 6 (strong pain)

$\mathrm{n}=12$

7 or 8 (very severe pain)

$\mathrm{n}=7$

$20.60 \%$

9 or 10 (unbearable pain)

$\mathrm{n}=6$

0 to 3 scores Without Disability

$\mathrm{n}=4$

$11.80 \%$

4 to 12 scores Mild Disability

$\mathrm{n}=19$

$55 \%$

13 to 17 scores Moderate

Disability

$\mathrm{n}=10$

$29.40 \%$

$>18$ scores Severe Disability

$\mathrm{n}=1$

$2.90 \%$

Mean and Standard Deviation $\quad 8.6 \pm 5$

Source: Survey data (2021)

\section{Discussion}

The analysis of the results obtained made it possible to observe that $36 \%$ of the participants are between 33 and 42 years old, similar to the study by Lemos, Marqueze and Moreno [18], whose data on the participants had a similar age range, from 30 to 39 years old, representing $36 \%$ of the sample of this research. In this context, Mascarenhas [19] point to a correlation between older ages as a risk factor for the onset of low back pain.

With regard to the body mass index (BMI), the sample in this study showed overweight (44\%) and obesity II (46\%) as a condition common to this working class. Masson and Monteiro [22] observed that most research participants were overweight, that is, they had a BMI between 25 and $29.9 \mathrm{~kg} / \mathrm{m}^{2}(40.9 \%)$, with a mean BMI of $27.5 \mathrm{~kg} / \mathrm{m}^{2}$. Fernández-D’Pool [20], in turn, assert that overweight can be a triggering factor for pain in skeletal muscles.

Oliveira, Sesti and Oliveira [21], in a study on lipid and glycemic profile in truck drivers in the central region of Rio Grande do Sul, observed that $51.6 \%$ of the sample had cholesterol levels above the values considered normal and, 
in relation to blood glucose levels, $13.18 \%$ had hyperglycemia. Furthermore, according to data from our research, it was also possible to observe that $22 \%$ of the participants had hypertension as a chronic pathology, only $6 \%$ had altered cholesterol and $2 \%$ had diabetes mellitus. Therefore, this elevated picture of hypertension may be related to the prolonged use of the rivet, which has an adverse effect of raising blood pressure.

Barros, Bastos and Lopes [22] showed a correlation between the active duration of the profession and the appearance of low back pain. In addition, it was found that participants who had low back pain had an average of 23.4 years of experience. Similarly, the findings of this study show us that $38 \%$ of the participants reported having more than 21 years in the profession. Which allows us to infer that time in the profession can be considered a contributing factor to the emergence of low back pain.

With regard to the characteristics of the type of profession analyzed in this study, it was observed that $62 \%$ work as self-employed persons. According to the data obtained, they make 2 trips a month (76\%), with an average duration of 10 to 14 days (80\%) each. These professionals drive more than 16 hours a day (40\%) and report sleeping less than 6 hours (64\%) a day. Similarly, Penteado [23] identifies a prevalence among self-employed professionals (59.5\%). However, they pointed out divergences in relation to the duration of the journey, 11 to 13 hours (29\%), and also the time allotted to sleep, on average 8 to 9 hours (38\%). In this context, Alessi and Alves [24] report that truck drivers do not have a good quality of sleep, directly affecting their professional performance.

In addition, it is worth noting that the use of an uncomfortable seat and lack of back support had a considerable relationship with low back pain in drivers [24]. Thus, it is possible to observe that the excess hours worked per day, as well as poor sleep quality and ergonomic factors can contribute to the onset of low back pain and interfere with the health of these professionals.

Regarding bad habits related to health care, Lemos, Marqueze and Monteiro [18] state that $65.5 \%$ of the research sample carried out by them consumed alcoholic beverages, as well as $61.8 \%$ were non-smokers. Likewise, in the present research, it was possible to observe that the majority consume alcoholic beverages (52\%), and most participants were non-smokers (96\%).

Regarding the use of psychoactive substances, $40 \%$ of truck drivers reported using nobésio (rivet), a drug from the amphetamine family, which causes alterations in the sleep-wake cycle. Alessi and Alves [24] found similar results, pointing out that $46 \%$ of their research sample reported using this medication. However, according to the authors, the use of this substance may be related to three main factors: economic reasons, company pressure and dependence. With regard to low back pain, 68\% of the sample in this study had this clinical picture. Of these, 35.3\% classified the intensity of this pain as severe pain, with scores of 5 and 6 , according to the visual analogue scale (VAS). Consequently, when asked about the degree of incapacity for work, 55.9\% reported having mild incapacity, with scores from 4 to 12, due to LD, according to the application of the Rolland Morris questionnaire.

Finally, Pedrosa [26] concluded that, of the 30 participants in their sample, 29 experiences chronic nonspecific low back pain. On the other hand, Barros, Bastos and Lopes [31], in their study, showed divergences in relation to the VAS, with an average score of 2.2 and the Rolland Morris questionnaire, with an average of 5.2. 


\section{AJAST}

Asian Journal of Applied Science and Technology (AJAST)

Volume 5, Issue 3, Pages 01-12, July-September 2021

\section{Final Considerations}

In view of what has been exposed in this study, it can be concluded that the result was positive for the proposed theme, as it showed a prevalence of $68 \%$ of low back pain in truck drivers in the city of Tabuleiro do Norte, linked to ACATAN. The studied sample, in turn, classified the intensity of low back pain as severe and the degree of disability as mild. The study also pointed out high rates of obesity and overweight of the participating individuals. The cause of this, among other reasons, can be explained by the finding of habits that are harmful to health, such as the use of nobésio (rivet) and the consumption of alcoholic beverages. In this same sense, it is possible to relate the LBP to the higher BMI, the prolonged time in occupations performed in a sitting position and the organization of the work position.

In this sense, it is worth emphasizing the need for educational actions aimed at promoting the health of these workers and related to work organization, nutrition and quality of life. However, this research does not exhaust the possibilities of new discoveries on the subject, but rather induces new questions. Therefore, it is suggested that further studies be carried out with larger numbers of participants from this working class, aiming at the prevention of musculoskeletal disorders. For future studies, it is important to know now the food profile, as well as endocrine or metabolic diseases of truckers.

\section{Declarations}

\section{Source of Funding}

This research did not receive any grant from funding agencies in the public, commercial, or not-for-profit sectors.

\section{Competing Interests Statement}

The authors declare no competing financial, professional and personal interests.

\section{Ethical Approval}

Ethical approval for this research was based on institutional guidelines.

\section{Consent for publication}

Authors declare that they consented for the publication of this research work.

\section{Availability of data and material}

Authors are willing to share data and material according to the relevant needs.

\section{References}

1. ML Morais, VK Silva, JM Silva, Prevalence of low back pain and associated factors among physiotherapy students, Brazilian Journal Pain 243 (2018) 241-247. Available at:

https://www.scielo.br/pdf/brjp/v1n3/1806-0013-brjp-01- 03-0241.pdf. Accessed on: 13 Mar. 2020.

2. ZA Cargnin, DG Schneider, MAO Vargas, IJC Schneider, Work activities and chronic nonspecific low back pain in nursing workers, Paulista Nursing Act 326 (2019) 707-713. Available at: 
Asian Journal of Applied Science and Technology (AJAST)

Volume 5, Issue 3, Pages 01-12, July-September 2021

https://www.scielo.br/scielo.php?script=sci_arttext\&pid=S0103-21002019000600707. Accessed on: 09 mar. 2020.

3. PRC Nascimento, LOP Costa, Prevalence of low back pain in Brazil: a systematic review, Public Health Notebook 316 (2015) 1141-1155. Available at:

https://www.scielo.br/pdf/csp/v31n6/0102-311X-csp-31-6-1141.pdf. Accessed on: 13 Mar. 2020.

4. Brazilian Institute Of Geography And Statistics. National Household Sample Survey: An overview of health in Brazil: access and use of services, health conditions and risk factors and health protection. Available at:

https://biblioteca.ibge.gov.br/visualizacao/monografias/GEBIS\%20-\%20RJ/panorama.pdf. Accessed on: 16 Mar. 2020.

5. RNV Furtado, LH Ribeiro, BA Abdo, FJ Descio, CEM Junior, DC Serruyaet, Nonspecific low back pain in young adults: associated risk factors, Brazilian Journal of Rheumatology 545 (2014) 371-377. Available at: https://www.scielo.br/pdf/rbr/v54n5/0482-5004-rbr-54-05-0371.pdf. Accessed on: 10 mar. 2020.

6. MROGC Silva, AFV Badaró, MM Dall'agnol, Low back pain in adolescent and associated factors: A cross sectional study with schoolchildren, Brazilian Journal of Physical Therapy 185 (2014) 402-409. Available at: https://www.scielo.br/scielo.php?script=sci_arttext\&pid=S1413-35552014000500402. Accessed on: 02 Mar. 2020.

7. DT Lizier, MV Perez, RK Sakata, Exercises for the Treatment of Nonspecific Low Back Pain, Brazilian Journal of Anesthesiology 626 (2012) 842-846. Available at: https://www.scielo.br/pdf/rba/v62n6/v62n6a08. Accessed on: 13 Mar. 2020.

8. JBM Valença, MCB Alencar, Absence from work due to low back pain and the repercussions on health: old questions and challenges that remain, Brazilian Journal of Occupational Therapy 261 (2018)119-127. Available at: www.cadernosdeterapia Ocupacional.ufscar.br/index.php/cadernos/article/view/1838. Accessed on: 16 Mar. 2020. 9. MG Matos, EA Hennington, AL Hoefel, JS Dias-da-Costa, Low back pain in users of a health plan: prevalence and associated factors, Public Health Notebook 249 (2008) 2115-2122. Available at: https://www.scielo.br/scielo. php? script=sci_arttext\&pid=S0102-311X2008000900017. Accessed on: 13 Mar. 2020.

10. SF Andrusaitis, RP Oliveira, FTEP Barros, Study Of The Prevalence And Risk Factors For Low Back Pain In Truck Drivers In The State Of São Paulo, Brazil, Clinics 616 (2006) 503-510. Available at: www.scielo.br/scielo. php? script=sci_arttext\& pid=S1807-59322006000600003. Accessed on: March 16th. 2020.

11. MAG Palácio, PA Inhoti, SG Palácio, Accidents and occupational diseases related to workers in the cargo transport sector in Brazil in the period 2010 and 2011, Health and Research Journal 83 (2015) 451-460. Available at: https://periodicos.unicesumar.edu.br/index.php/saudpesq/article/view/4305. Accessed on: 16 Mar. 2020.

12. FGF Pereira, RA Aquino, VDM Alencar, AMJ Pordeus, MBC Ataíde, Relationship between work process and health of truck drivers, Brazilian Journal of Health Promotion 274 (2014) 462-469. Available at:

https://periodicos.unifor.br/RBPS/article/view/2960. Accessed on: 16 Mar. 2020. 
13. A. Castro, Tabuleiro do Norte: Cidade da gente. Fortaleza, Ceará, 2018.

14. RRBT Maciel, NC Santos, DDA Portella, PGJM Alves, BP Martinez, Effects of physical exercise in the work environment in the treatment of low back pain: a systematic review with meta-analysis, Brazilian Journal of Occupational Medicine 62 (2018) 225-235. Available at:

http://www.rbmt.org.br/details/319/pt-BR/efeitos-do-exercicio-fisico-no-ambiente-de-trabalho-no-tratamento-dador-lombar--uma-revisao-sistematica-com-metanalise. Accessed on: 15 Mar. 2020.

15. FR Teixeira, LR Mayr, AV Paisana, FD Vieira, Methodological choices in scientific research: application of the Saunders approach to the study of the influence of culture on cluster competitiveness, RIST Iberian Journal of Information Systems and Technologies 2 (2014) 85-98. Available at:

http://www.scielo.mec.pt/pdf/rist/nspe2/nspe2a07.pdf. Accessed on: May 142021.

16. M Nookdzij, FW Dekker, C Zoccali, KJ Jager, Sample size calculations, Nephron Clin Pract 1184 (2011) 319-323. Available at: https://pubmed.ncbi.nlm.nih.gov/21293154/. Accessed on: May 142021.

17. L. Nusbaum, J. Natour, MB Ferraz, J. Goldenberg, Translation, adaptation and validation of the Roland-Morris questionnaire - Brazil Roland-Morris, Brazilian Journal of Medical and Biological Reserach 342 (2001) 203-210. Available at: https://www.scielo.br/scielo.php? script=sci_arttext\&pid=S0100-879X2001000200007. Accessed on: Apr 42020.

18. LC Lemos, EC Marqueze, CRC Moreno, Prevalence of musculoskeletal pain in truck drivers and associated factors, Brazilian Journal of Occupational Health 39129 (2014) 26-34.

Available at: https://www.scielo.br/pdf/rbso/v39n129/0303-7657-rbso-39-129-0026.pdf. Accessed on: May 10 2021.

19. CHM Mascarenhas, JSR Filho, RL Melo, DC Silva, Prevalence of low back pain in taxi drivers in the city of Jequié-BA, Espaço para Saúde-Public Health Journal of Paraná 151 (2014) 66-76. Available at:

https://espacoparasaude.fpp.edu.br/index.php/espacosaude/article/view/540. Accessed on: May 102021.

20. J. Fernández-D'pool, F. Vélez, A. Brito, C. D'Pool, Musculoskeletal symptoms in bus drivers of a university institution, Journal of Clinical Investigation 532 (2012) 125-137. Available at:

https://pubmed.ncbi.nlm.nih.gov/22978045. Accessed on: 11 May. 2021.

21. LV Oliveira, LFC Sesti, SV Oliveira, Lipid and glycemic profile in truck drivers in the central region of the state of Rio Grande do Sul, Scientia Plena 812 (2012) 1-6. Available at:

https://www.scientiaplena.org.br/sp/article/view/956. Accessed on: May 12th 2021.

22. FP Barros, RFN Bastos, RL Lopes, Prevalence of low back pain in private network truck drivers, Health sciences and applied sciences from the West of Bahia-Hígia 51 (2020) 20-35. Available at: http://fasb.edu.br/revista/index.php/higia/article/view/527. Accessed on: 11 May. 2021.

23. RZ Penteado, CO Giglio, DDC Gonçalves, JM Marques, Work and health among truck drivers in the interior of São Paulo, Health and Society 174 (2008) 35-45. Available at: 
https://www.scielo.br/scielo.php?script=sci_arttext\&pid=S0104-12902008000400005\&lng=pt\&tlng=pt.

Accessed on: 11 May. 2021.

24. A. Alessi, MK Alves, Life habits and health conditions of truck drivers in Brazil: a literature review, Science and health 83 (2015) 129-136. Available

at:https://revistaseletronicas.pucrs.br/ojs/index.php/faenfi/article/view/18184. Accessed on: May 12th. 2021.

25. D. Alperovitch-Najenson, Y. Santo, Y. Masharawi, M. Katz-Leurer, D. Ushvaev, L. Kalichman, Low back pain among professional bus drivers: ergonomic and occupational-psychosocial risk factors, Israel Medical Association Journal 121 (2010) 26-31. Available at: https://pubmed.ncbi.nlm.nih.gov/20450125/. Accessed on: May 12th.

2021.

26. AAS Pedrosa, AC Reis, RRS Souza, NDA Rabelo, PRG Lucareli, Bley AS, Disability index of low back pain in truck drivers, ABCS Health Sciences 383 (2013) 142-145. Available at:

https://pesquisa.bvsalud.org/portal/resource/pt/lil-698568. Accessed on: May 132021. 